\title{
Temperature effect on fracture toughness of CLF-1 steel with miniature three-point bend specimens
}

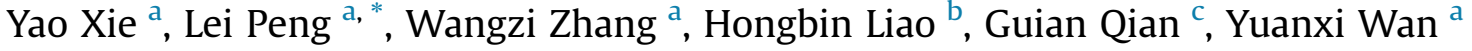 \\ a University of Science and Technology of China, Hefei, 230027, China \\ b Southwestern Institute of Physics, Chengdu, 610041, China \\ ${ }^{\mathrm{c}}$ Institute of Mechanics, Chinese Academy of Sciences, Beijing, 100190, China
}

\section{H I G H L I G H T S}

- The fracture toughness J0.2(B) of CLF-1 steel decreases from $25^{\circ} \mathrm{C}$ to $450{ }^{\circ} \mathrm{C}$ and increases from $450{ }^{\circ} \mathrm{C}$ to $550{ }^{\circ} \mathrm{C}$.

- The load-line displacement of miniature 3 PB specimens was measured by a 3D-DIC method.

- Few typical dimples observed at $450{ }^{\circ} \mathrm{C}$ indicated quasi-cleavage-like features.

\section{A R T I C L E I N F O}

\section{Article history:}

Received 13 October 2019

Received in revised form

2 January 2020

Accepted 9 January 2020

Available online 13 January 2020

\section{Keywords:}

RAFM steel

Fracture toughness

Temperature effect

CLF-1

\begin{abstract}
A B S T R A C T
Fracture toughness is one important mechanical property of reduced activation ferritic/martensitic (RAFM) steels which are primary candidate structural materials applied to fusion reactors. Temperature effect on fracture toughness of the Chinese low activation ferritic/martensitic (CLF-1) steel was investigated in the range of $25-550{ }^{\circ} \mathrm{C}$ with miniature three-point bend (3PB) specimens, using the digital image correlation (DIC) method to measure load-line displacement. Results show that the fracture toughness $\mathrm{J}_{0.2(\mathrm{~B})}$ of CLF-1 steel decreases from $25^{\circ} \mathrm{C}$ to $450{ }^{\circ} \mathrm{C}$ and increases from $450{ }^{\circ} \mathrm{C}$ to $550{ }^{\circ} \mathrm{C}$. This changing trend with temperature is similar to that of some commercial ferritic/martensitic (F/M) steels and consistent with the temperature dependence of its ductility which is total elongation obtained from tensile testing. The fracture toughness minimum at $450{ }^{\circ} \mathrm{C}$ could be attributed to the deterioration of ductility, where the fracture surfaces with few typical dimples indicated quasi-cleavage-like features.
\end{abstract}

(c) 2020 Elsevier B.V. All rights reserved.

\section{Introduction}

Reduced activation ferritic/martensitic (RAFM) steels, considered as primary candidate structural materials for a demonstration (DEMO) fusion plant and the first fusion power reactors [1-5], will be subjected to high irradiation damage and elevated temperatures. In the severe environment, fracture toughness is an important engineering property of RAFM steels. Because of the thin-wall structure of fusion blankets and space limitation in irradiation volume for structural materials, there is a high demand for specimen miniaturization [6-8]. Miniature specimens were used in most of the studies [9-16] on fracture toughness of RAFM steels at different temperatures [9-19]. For JLF-1 steel, the fracture toughness was evaluated at room temperature [11-13]. For CLAM steel,

\footnotetext{
* Corresponding author.

E-mail address: penglei@ustc.edu.cn (L. Peng).
}

the fracture toughness was obtained at room temperature $[9,10]$, $450{ }^{\circ} \mathrm{C}$ and $500{ }^{\circ} \mathrm{C}$ [17], respectively. As for other types of RAFM steels, such as F82H [14,18,19], EUROFER97 [15], Optimax [14], and $9 \mathrm{Cr}-2 \mathrm{WVTa}$ [18], the fracture toughness was evaluated from room temperature to no more than $250{ }^{\circ} \mathrm{C}$. Therefore data on fracture toughness at high temperatures are limited, considering that the service temperature of RAFM steels reaches up to $550{ }^{\circ} \mathrm{C}[20]$. Besides, for commercial ferritic/martensitic (F/M) steels [21-23], such as HT-9 [23], the fracture toughness decreased from room temperature $25{ }^{\circ} \mathrm{C}-250{ }^{\circ} \mathrm{C}$ and then increased from $250{ }^{\circ} \mathrm{C}$ to $550{ }^{\circ} \mathrm{C}$. Although RAFM steels and commercial F/M steels are similar, it is unclear whether the temperature effect on fracture toughness of RAFM steels is similar to that of commercial F/M steels.

Since fracture toughness values are usually size-dependent [10-13], it is difficult to determine plain-strain fracture toughness $\mathrm{K}_{\mathrm{IC}}$ or JIC of RAFM steels with high ductility and toughness, especially for compact tension (CT) specimens. In respect of specimen 
Table 1

Tensile properties of CLF-1 steel at different temperatures [29].

\begin{tabular}{lllll}
\hline $\mathrm{T}\left({ }^{\circ} \mathrm{C}\right)$ & $\mathrm{E}(\mathrm{GPa})$ & YS $(\mathrm{MPa})$ & UTS $(\mathrm{MPa})$ & TE $(\%)$ \\
\hline 25 & 224 & 555 & 668 & 22 \\
250 & 213 & 488 & 568 & 17 \\
350 & 205 & 456 & 527 & 14 \\
450 & 194 & 421 & 473 & 15 \\
550 & 182 & 340 & 376 & 22 \\
\hline
\end{tabular}

T: temperature, E: Young's modulus, YS: yield stress, UTS: ultimate tensile stress, TE: total elongation. especially for irradiated specimens.

In this paper, temperature effect on fracture toughness of the Chinese low activation ferritic/martensitic (CLF-1) steel was investigated in the range of $25-550{ }^{\circ} \mathrm{C}$ with $3 \mathrm{~PB}$ miniature specimens. A DIC method was applied to measure the load-line displacement of the 3PB specimens. Fractographs were also examined to find fracture characteristics and identify fracture types.

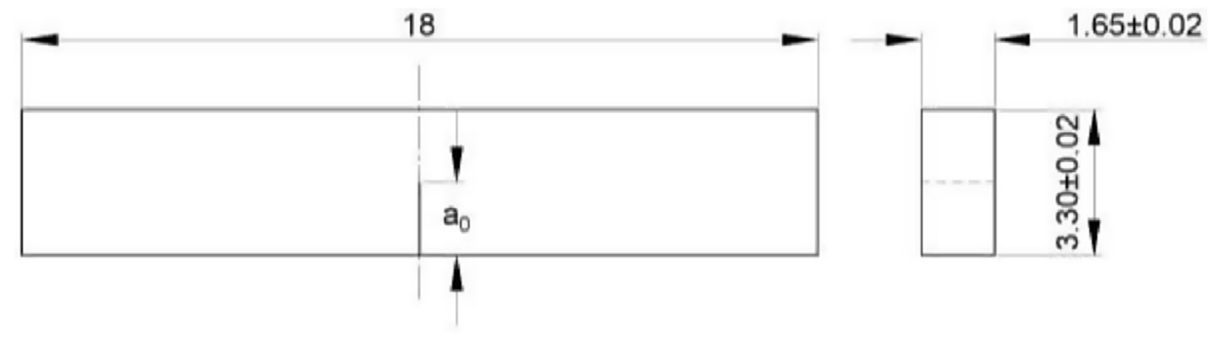

Fig. 1. Shape and size of the 3PB specimen (unit: mm).

miniaturization and preparation, 3PB specimens show advantages over CT ones, but load-line displacement of 3PB specimens cannot be correctly measured by clip gages [13]. It is also difficult to use clip gages at high temperatures because complex devices have to be used [24]. Therefore a digital image correlation (DIC) method [25-27], a non-contact optical method of full-field displacement measurement, was used to directly measure the load-line displacement in this study. It could be a convenient and effective method of measuring displacement for nuclear materials [28],

Table 2

Test temperature and $\mathrm{a}_{0} / \mathrm{W}$ of the 3PB specimens.

\begin{tabular}{llllll}
\hline Temperature $\left({ }^{\circ} \mathrm{C}\right)$ & $\mathrm{a}_{0} / \mathrm{W}$ & $\mathrm{F}_{0}(\mathrm{~N})$ & $v_{0}(\mathrm{~mm})$ & $\Delta v / \Delta \mathrm{F}(\mathrm{mm} / \mathrm{N})$ & $\mathrm{J}_{0.2(\mathrm{~B})}\left(\mathrm{kJ} / \mathrm{m}^{2}\right)$ \\
\hline 25 & 0.550 & 304 & 0.99 & 0.08 & 463 \\
& 0.596 & 218 & 1.14 & 0.10 & 439 \\
250 & 0.529 & 319 & 0.83 & 0.03 & 436 \\
& 0.526 & 332 & 0.84 & 0.05 & 389 \\
350 & 0.477 & 358 & 0.80 & 0.03 & 425 \\
& 0.537 & 254 & 0.54 & 0.04 & 337 \\
450 & 0.500 & 287 & 0.48 & 0.05 & 265 \\
\multirow{2}{*}{550} & 0.462 & 324 & 0.53 & 0.04 & 321 \\
& 0.544 & 247 & 0.87 & 0.03 & 275 \\
& 0.474 & 290 & 0.94 & 0.04 & 393 \\
\hline
\end{tabular}

\section{Material and methods}

The material used in this study was CLF-1 steel produced by vacuum induction melting method. The steel was fabricated from a 5-ton ingot and supplied as hot-rolled plates with $30 \mathrm{~mm}$ in thickness. The chemical composition of this steel in wt\% is Fe-0.12C$8.50 \mathrm{Cr}-1.50 \mathrm{~W}-0.25 \mathrm{~V}-0.10 \mathrm{Ta}-0.51 \mathrm{Mn}$. The steel was normalized at $980^{\circ} \mathrm{C}$ for $45 \mathrm{~min}$ and then tempered at $740^{\circ} \mathrm{C}$ for $90 \mathrm{~min}$. Both the normalizing and tempering heat treatments were followed by air quenching [29]. Tensile properties of CLF-1 steel are listed in Table 1. All specimens were pre-cracked subjected to fatigue loading under force control at a frequency of $101 \mathrm{~Hz}$. Temperature was kept at $23{ }^{\circ} \mathrm{C}$ during the pre-cracking. Fig. 1 shows the shape and size of the 3PB specimen. The ratio of original crack length to the width, i.e. $a_{0} / \mathrm{W}$, measured by an optical microscope, is in the range of $0.46-0.60$. The specimen span $\mathrm{S}$ equals to $4 \mathrm{~W}$ for all the specimens.

Test temperatures and $\mathrm{a}_{0} / \mathrm{W}$ of the 3 PB specimens are listed in Table 2. Two specimens were tested at each temperature in a MTS machine. Accuracy of force measurement was within $\pm 0.1 \%$ of the working range. In the test, the specimens were heated in a vacuum furnace below $10 \mathrm{~Pa}$. The temperature during test was measured with an accuracy of $\pm 1{ }^{\circ} \mathrm{C}$. The specimens were held at the test temperature for $30-40 \mathrm{~min}$ at the beginning of each test. After test,

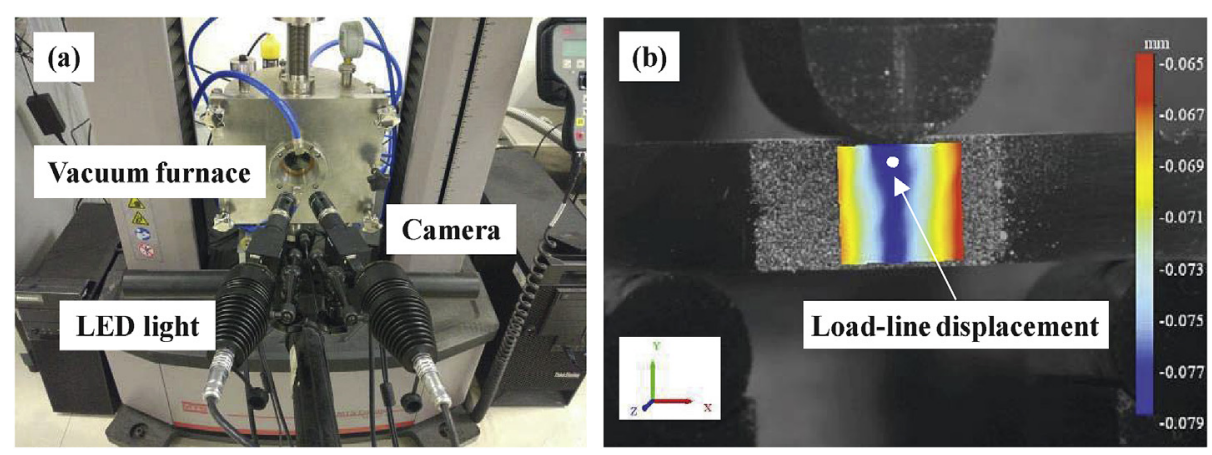

Fig. 2. (a) Experimental setup of the 3D-DIC system; (b) Displacement field in form of contour plot. 

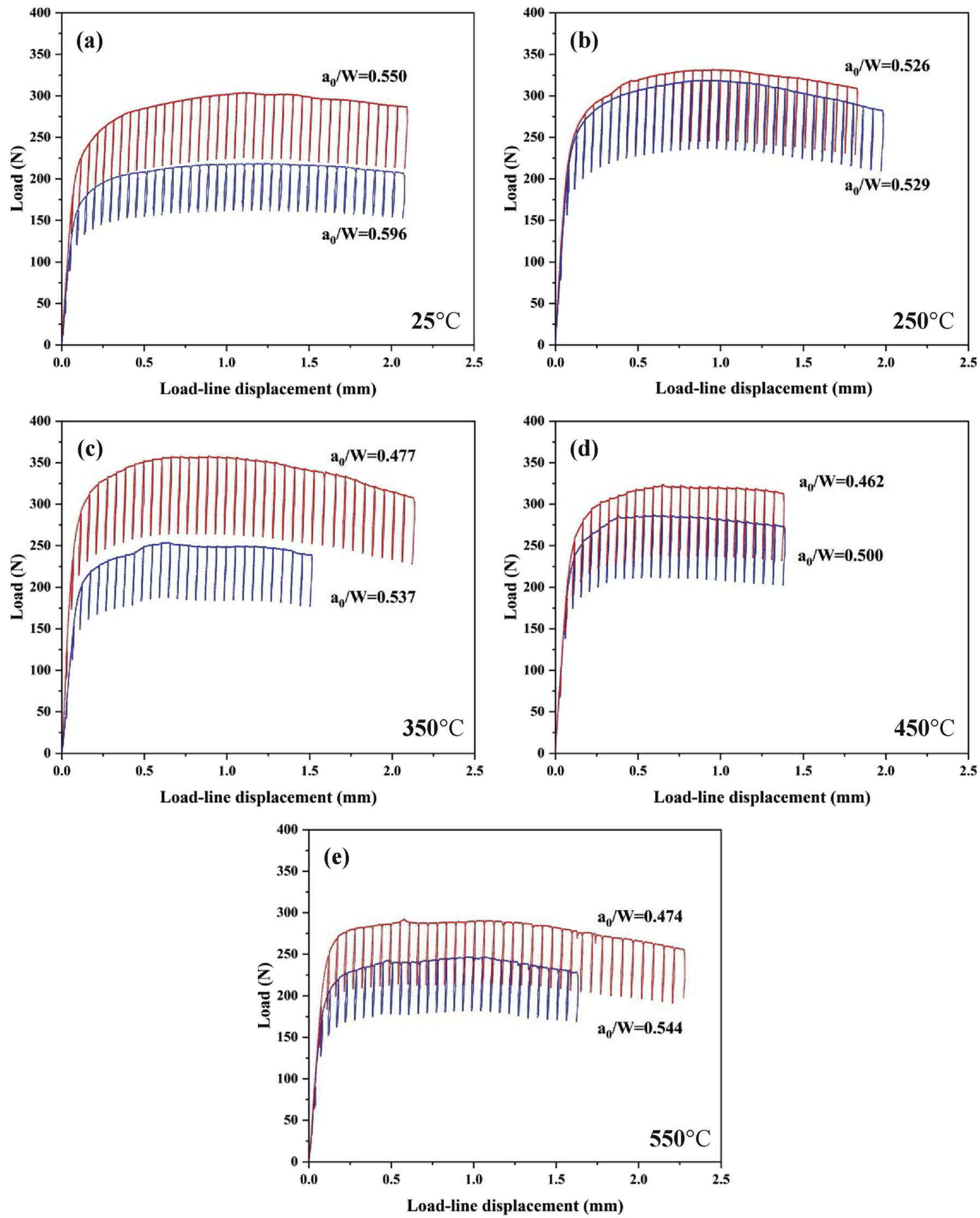

Fig. 3. The load versus load-line displacement curves at different temperatures. 

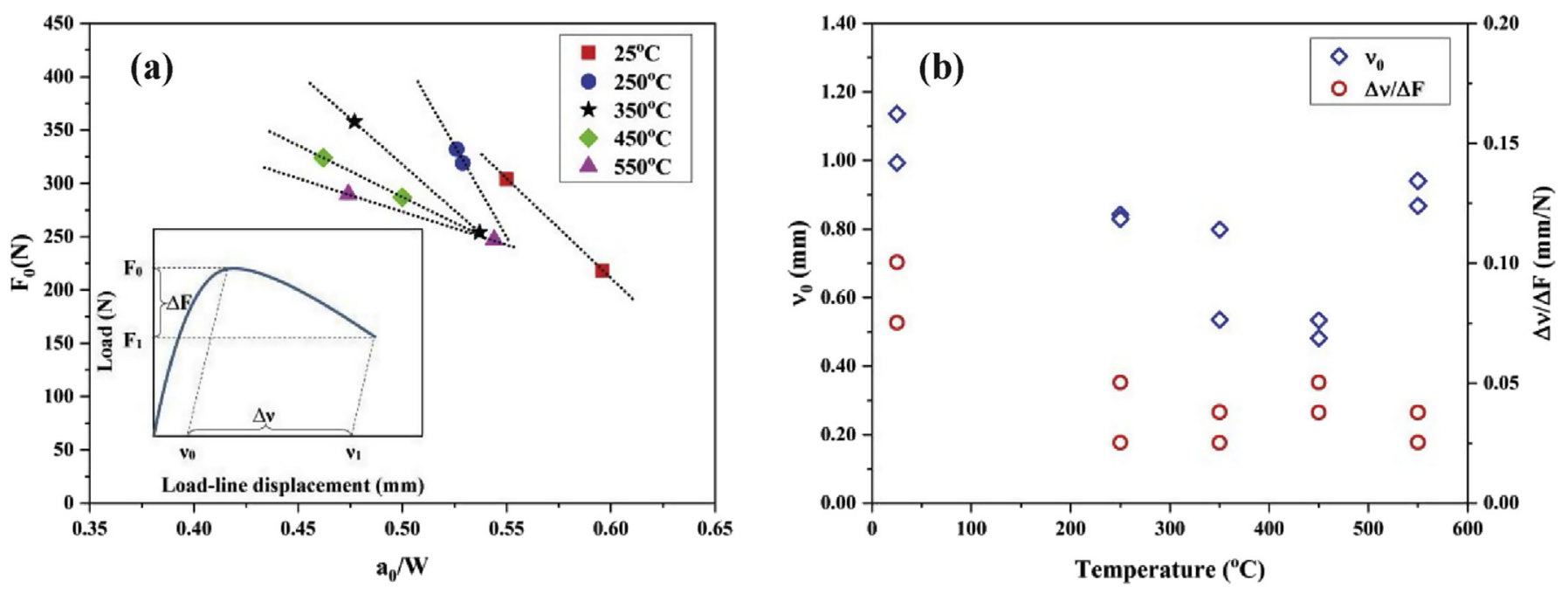

Fig. 4. (a) Effect of $a_{0} / W$ and temperature on $F_{0}$; (b) Effect of temperature on $v_{0}$ and $\Delta v / \Delta F$.

the specimens were tinted at $250^{\circ} \mathrm{C}$ for $20 \mathrm{~min}$ and then broken in half in liquid nitrogen atmosphere. The fracture surfaces were examined in a Zeiss scanning electron microscope (SEM). The original crack length $\mathrm{a}_{0}$ was measured again and verified by a ninepoint average procedure based on the SEM measurement obtained from the post-test fracture surface, as shown in Table 2.

The load-line displacement was measured by the 3D-DIC method [30-32]. Fig. 2a shows the experimental setup of the 3DDIC system, which consists of two LED lights and two cameras. The load-line displacement was obtained from the displacement field of specimen surface given in the form of contour plot [33], as shown in Fig. 2b. The load-line displacement of a 3PB specimen is defined as the vertical displacement of the load point on the specimen from its original position as a consequence of loading [34,35].

The unloading compliance method was applied following ISO 12135 requirement [34]. The specimens were loaded under crosshead-displacement control at a constant speed of $0.1 \mathrm{~mm} / \mathrm{min}$. The maximum range of unload/reload cycles was $25 \%$ of the current force. The unload/reload cycles were spaced with the crosshead displacement interval at $0.05 \mathrm{~mm}$. The specimen compliance was subsequently used to estimate the crack length. A size-dependent fracture toughness value, $\mathrm{J}_{0.2(\mathrm{~B})}$, is defined as the intersection of the regression line and the $0.2-\mathrm{mm}$ offset line in the J-R curve.

\section{Results and discussion}

\subsection{Load-displacement relations}

Fig. 3 shows the load versus load-line displacement relations at $25^{\circ} \mathrm{C}, 250{ }^{\circ} \mathrm{C}, 350^{\circ} \mathrm{C}, 450{ }^{\circ} \mathrm{C}$ and $550{ }^{\circ} \mathrm{C}$. These curves are smooth and the applied forces slowly decline with displacement after the peak, indicating that the crack propagated stably with good toughness. For the two specimens tested at the same temperature, the difference in their peak forces is caused by the different $a_{0} / W$ values. After the peak, the decrease rates of force are similar at the same temperature and change with increasing temperatures.

A schematic diagram of load-displacement curves is given in Fig. $4 a$, in which the unload/reload cycles are omitted. $F_{0}$ is the peak force and $v_{0}$ is the corresponding plastic component of total displacement. $\Delta \mathrm{F}$ is the force reduction after the peak and $\Delta v$ is the corresponding change of plastic displacement. The values of $F_{0}, v_{0}$ and $\Delta \mathrm{F} / \Delta v$ are shown in Table 2. Fig. 4a indicates that the peak forces at the same temperature decline with increasing $\mathrm{a}_{0} / \mathrm{W}$. When the $\mathrm{a}_{0} / \mathrm{W}$ values are similar, the peak forces decline with increasing temperature. The peak force variety seems to be more sensitive to $\mathrm{a}_{0} / \mathrm{W}$ than to test temperature. For example, the difference in the peak forces of two specimens with similar $\mathrm{a}_{0} / \mathrm{W}$ (about 0.550 ) is only $57 \mathrm{~N}$ at different temperatures $\left(25^{\circ} \mathrm{C}\right.$ and $\left.550{ }^{\circ} \mathrm{C}\right)$. In contrast, the difference in the peak forces of another two specimens with different $\mathrm{a}_{0} / \mathrm{W}(0.477$ and 0.534$)$ reaches up to $104 \mathrm{~N}$ at the same temperature $\left(350{ }^{\circ} \mathrm{C}\right)$. Besides, the decreasing rates of the peak forces with increasing $\mathrm{a}_{0} / \mathrm{W}$ approximately decline with increasing

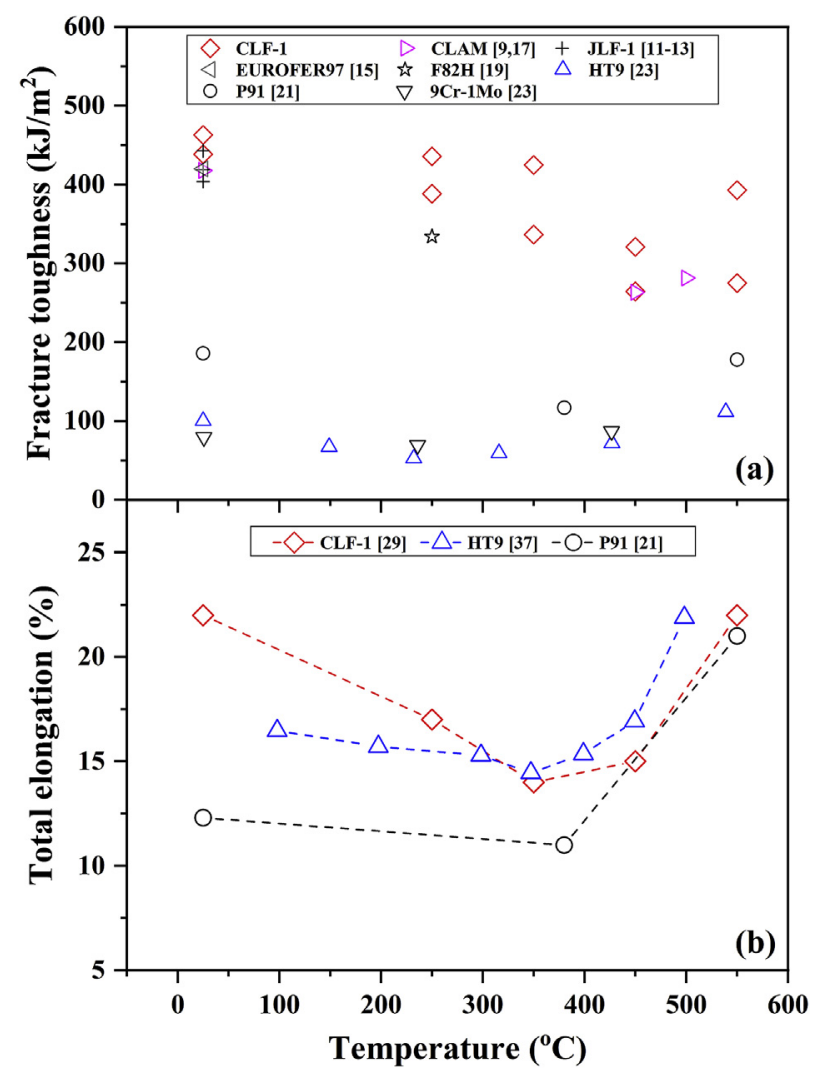

Fig. 5. (a) Effect of temperature on fracture toughness of CLF-1 steel and other steels [9,11-13,15,17,19,21,23]; (b) Effect of temperature on total elongation of CLF-1 steel [29] and other steels $[21,37]$. 
temperature.

Fig. $4 \mathrm{~b}$ shows the temperature effect on $v_{0}$ and $\Delta v / \Delta \mathrm{F}$. The $v_{0}$ values decrease with increasing temperature from $25^{\circ} \mathrm{C}$ to $450^{\circ} \mathrm{C}$, followed by an increase. The change of $v_{0}$ with temperature could be attributed to the change of ductility of CLF- 1 steel, as shown in Fig. $5 \mathrm{~b}$. A ductility minimum was found at about $400^{\circ} \mathrm{C} . \Delta v / \Delta \mathrm{F}$ is the average change rate of plastic displacement per force reduction after the peak force. A lower $\Delta v / \Delta \mathrm{F}$ value indicates that the crack tends to propagate more easily. The $\Delta v \Delta \mathrm{F}$ values decrease from $25^{\circ} \mathrm{C}$ to about $400^{\circ} \mathrm{C}$ and increase from about $400^{\circ} \mathrm{C}$ to $550^{\circ} \mathrm{C}$. This finding is consistent with the result of RAFM steels which showed that the crack propagation rate changed with tensile test temperature and peaked at about $400{ }^{\circ} \mathrm{C}$ [36].

\section{2. $J_{0.2(B)}$-temperature relations}

Although the obtained fracture toughness $\mathrm{J}_{0.2(B)}$ values are not qualified as Jic for the miniature specimens which always cannot fully satisfy the requirements of ISO 12135 , the $\mathrm{J}_{0.2(\mathrm{~B})}$ values still contribute to understanding temperature effect on the fracture toughness of RAFM steels. Since the $\mathrm{J}_{0.2(B)}$ values also represent the fracture toughness of RAFM steels, the temperature dependence of $\mathrm{J}_{0.2(\mathrm{~B})}$ can characterize that of $\mathrm{J}_{\mathrm{IC}}$ to some extent. As shown in Fig. $5 \mathrm{a}$ and Table 2, the Jo.2(B) values of CLF-1 steel decline from $25^{\circ} \mathrm{C}$ to
$450{ }^{\circ} \mathrm{C}$ and then rise from $450{ }^{\circ} \mathrm{C}$ to $550{ }^{\circ} \mathrm{C}$. This trend illustrates that an increase in temperature results in a decrease in crack propagation resistance below $450{ }^{\circ} \mathrm{C}$. When the temperature rise above $450{ }^{\circ} \mathrm{C}$, it becomes difficult for the crack to propagate. The changing trend of fracture toughness of CLF-1 steel with temperature is consistent with that of its ductility, the total elongation obtained from tensile testing. The ductility minimum at about $400{ }^{\circ} \mathrm{C}[21,29,37]$ shown in Fig. 5b results from dynamic strain aging (DSA) phenomenon, found in RAFM steels [36,38-40] and some commercial F/M steels [21,37]. The DSA phenomenon occurs due to the repeated pinning-unpinning dislocation motions by diffusing solute atoms, which usually causes a reduction of ductility and toughness [41]. Toughness represents a combined effect of strength and ductility. Since the strength of CLF-1 steel declines monotonously from $25^{\circ} \mathrm{C}$ to $550{ }^{\circ} \mathrm{C}$, as shown in Table 1 , the increase in fracture toughness from $450{ }^{\circ} \mathrm{C}$ to $550^{\circ} \mathrm{C}$ could mainly be attributed to the rise in its ductility at above $450{ }^{\circ} \mathrm{C}$.

Most of the scattered $\mathrm{J}_{0.2(\mathrm{~B})}$ values of other RAFM steels seems to be in line with the changing trend of CLF-1 steel, especially when the values of CLAM steel at $450{ }^{\circ} \mathrm{C}$ [17] were smaller than those at room temperature [9] and $500{ }^{\circ} \mathrm{C}$ [17]. The fracture toughness variation of CLF-1 steel is similar to that of commercial F/M steels from $25^{\circ} \mathrm{C}$ to $550^{\circ} \mathrm{C}$. The fracture toughness minimum of both HT-9 and $9 \mathrm{Cr}-1 \mathrm{Mo}$ steels was at about $250{ }^{\circ} \mathrm{C}[23,42]$. Besides, the
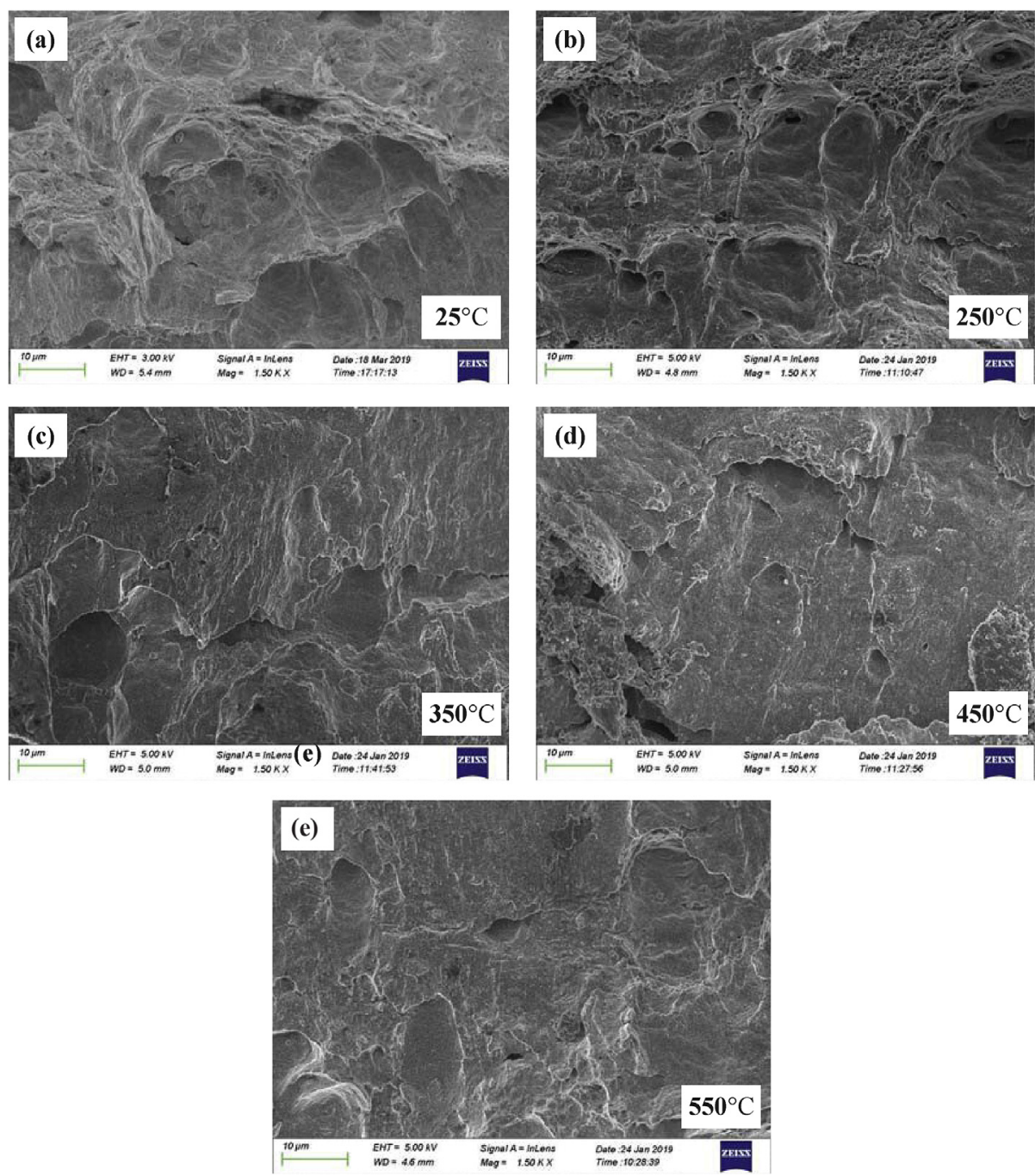

Fig. 6. Fracture surfaces of CLF-1 steel at different temperatures. 
fracture toughness minimum of P91 steel was at $380{ }^{\circ} \mathrm{C}[21]$.

\subsection{Fractography}

To investigate temperature effect on the fracture toughness of CLF-1 steel from fracture characteristics, the fracture surfaces were examined in an SEM machine, as shown in Fig. 6. Although CLF-1 steel exhibited ductile fracture at macroscopic scale throughout the test temperature range, some differences were found in the fracture surfaces at different test temperatures. The fractographs of specimens could roughly fall into three categories with different temperatures: (i) $25^{\circ} \mathrm{C}$ and $250{ }^{\circ} \mathrm{C}$, (ii) $350^{\circ} \mathrm{C}$ and $450{ }^{\circ} \mathrm{C}$, and (iii) $550{ }^{\circ} \mathrm{C}$. Both the fracture surfaces at $25^{\circ} \mathrm{C}$ and $250{ }^{\circ} \mathrm{C}$ exhibited rough and significant dimple structures, indicating ductile fracture characteristics. There were some large deep dimples and a group of small dense ones. For the specimens at $350^{\circ} \mathrm{C}$ and $450{ }^{\circ} \mathrm{C}$, typical dimples were hard to find on the fracture surfaces, which exhibited quasi-cleavage-like features corresponding to low fracture toughness shown in Fig. 5a. In detail, the fracture surfaces were corrugated with some discrete short ridges. When the test temperature rose up to $550{ }^{\circ} \mathrm{C}$, there were also some coarse dimples on the fracture surfaces and the specimens exhibited an increase in fracture toughness shown in Fig. 5a. Likewise, a few cleavage features were observed on the fracture surfaces of P91 steel at $380^{\circ} \mathrm{C}$, where the specimen showed a fracture toughness minimum [21]. The fractographs of HT-9 at $537{ }^{\circ} \mathrm{C}$ and P91 at $550{ }^{\circ} \mathrm{C}$ also exhibited typical dimples, where the fracture toughness values showed an increase [42].

\section{Conclusions}

Temperature effect on the fracture toughness of CLF- 1 steel was investigated in the range of $25-550{ }^{\circ} \mathrm{C}$ with miniature 3PB specimens, using the 3D-DIC method to measure load-line displacement. CLF-1 steel exhibited good ductility and toughness throughout the test temperature range. The fracture toughness $\mathrm{J}_{0.2(\mathrm{~B})}$ of CLF-1 steel decreases from $25^{\circ} \mathrm{C}$ to $450{ }^{\circ} \mathrm{C}$ and then increases from $450{ }^{\circ} \mathrm{C}$ to $550{ }^{\circ} \mathrm{C}$. This changing trend with temperature is similar to that of commercial $\mathrm{F} / \mathrm{M}$ steels in the range from $25{ }^{\circ} \mathrm{C}$ to $550{ }^{\circ} \mathrm{C}$, where the fracture toughness of both CLF- 1 and commercial $\mathrm{F} / \mathrm{M}$ steels increase after decreasing to a minimum. The temperature dependence of fracture toughness of CLF-1 is consistent with that of its ductility, the total elongation obtained from tensile testing. Since toughness represents a combined effect of strength and ductility and the strength of CLF-1 steel declines monotonously from $25{ }^{\circ} \mathrm{C}$ to $550{ }^{\circ} \mathrm{C}$, the fracture toughness minimum at $450{ }^{\circ} \mathrm{C}$ could be attributed to the deterioration of ductility, where few typical dimples were observed on the fracture surfaces, indicating quasi-cleavage-like features.

\section{Data availability}

The raw/processed data required to reproduce these findings cannot be shared at this time as the data also forms part of an ongoing study. The data that support the findings of this study will be later available from the corresponding author upon request.

\section{Declaration of competing interest}

The authors declare that they have no known competing financial interests or personal relationships that could have appeared to influence the work reported in this paper.

\section{CRediT authorship contribution statement}

Yao Xie: Conceptualization, Methodology, Investigation, Data curation, Visualization, Writing - original draft. Lei Peng: Funding acquisition, Project administration, Conceptualization, Methodology, Supervision, Writing - review \& editing. Wangzi Zhang: Formal analysis. Hongbin Liao: Resources. Guian Qian: Project administration. Yuanxi Wan: Supervision, Writing - review \& editing.

\section{Acknowledgements}

This work was supported by the China National Natural Science Foundation - NSAF with Grant No. U1730123.

\section{References}

[1] A.A.F. Tavassoli, Present limits and improvements of structural materials for fusion reactors - a review, J. Nucl. Mater. 302 (2-3) (2002) 73-88, https:// doi.org/10.1016/s0 022 -3115(02)00794-8.

[2] R.L. Klueh, D.S. Gelles, S. Jitsukawa, A. Kimura, G.R. Odette, B. van der Schaaf M. Victoria, Ferritic/martensitic steels - overview of recent results, J. Nucl. Mater. 307 (2002) 455-465, https://doi.org/10.1016/s0022-3115(02)01082-6.

[3] M. Abdou, N.B. Morley, S. Smolentsev, A. Ying, S. Malang, A. Rowcliffe, M. Ulrickson, Blanket/first wall challenges and required R\&D on the pathway to DEMO, Fusion Eng. Des. 100 (2015) 2-43, https://doi.org/10.1016/ j.fusengdes.2015.07.021.

[4] Y. Zhao, S. Liu, J. Shi, X. Mao, Experimental and numerical simulation analysis on creep crack growth behavior of CLAM steel, Mater. Sci. Eng. A-Struct. Mater. 735 (2018) 260-268, https://doi.org/10.1016/j.msea.2018.08.048.

[5] G.L. Liu, S.W. Yang, W.T. Han, L.J. Zhou, M.Q. Zhang, J.W. Ding, Y. Dong, F.R. Wan, C.J. Shang, R.D.K. Misra, Microstructural evolution of dissimilar welded joints between reduced-activation ferritic- martensitic steel and 316L stainless steel during the post weld heat treatment, Mater. Sci. Eng. A-Struct. Mater. 722 (2018) 182-196, https://doi.org/10.1016/j.msea.2018.03.035.

[6] G.E. Lucas, G.R. Odette, M. Sokolov, P. Spatig, T. Yamamoto, P. Jung, Recent progress in small specimen test technology, J. Nucl. Mater. 307 (2002) 1600-1608, https://doi.org/10.1016/S0022-3115(02) 01171-6.

[7] C. Yin, D. Terentyev, T. Pardoen, R. Petrov, Z. Tong, Ductile to brittle transition in ITER specification tungsten assessed by combined fracture toughness and bending tests analysis, Mater. Sci. Eng. A-Struct. Mater. 750 (2019) 20-30, https://doi.org/10.1016/j.msea.2019.02.028.

[8] P. Mueller, R. Bonadé, P. Spätig, Fracture properties of notched and precracked specimens of a tempered martensitic steel at low temperature, Mater. Sci. Eng. A-Struct. Mater. 483-484 (2008) 346-349, https://doi.org/ 10.1016/j.msea.2006.09.172.

[9] K.F. Li, S.J. Liu, Q.Y. Huang, G. Xu, S.B. Jiang, Fracture toughness of China low activation martensitic (CLAM) steel at room temperature, Fusion Eng. Des. 89 (4) (2014) 426-430, https://doi.org/10.1016/j.fusengdes.2014.03.076.

[10] S. Jiang, Q. Huang, J. Xin, Q. Wu, Fracture toughness of CLAM steel with 1/2CT specimens at room temperature and 150ć, Nucl. Sci. Eng. 36 (6) (2016) 790-794.

[11] A. Nishimura, N. Inoue, T. Muroga, Fracture toughness of low activation ferritic steel (JLF-1) weld joint at room temperature, J. Nucl. Mater. 258 (1998) 1242-1247, https://doi.org/10.1016/S0022-3115(98)00172-X.

[12] H. Ono, R. Kasada, A. Kimura, Specimen size effects on fracture toughness of JLF-1 reduced- activation ferritic steel, J. Nucl. Mater. 329 (2004) 1117-1121, https://doi.org/10.1016/j.j nucmat.2004.04.034.

[13] H. Kurishita, T. Yamamoto, T. Nagasaka, A. Nishimura, T. Muroga, S. Jitsukawa Fracture toughness of JLF-1 by miniaturized 3-point bend specimens with 3.3 $7.0 \mathrm{~mm}$ thickness, Mater. Trans. 45 (3) (2004) 936-941, https://doi.org/ 10.2320/mater tra ns.45.936.

[14] X. Jia, Y. Dai, The change of fracture toughness of martensitic steels after irradiation in SINQ target- 3, J. Nucl. Mater. 356 (1-3) (2006) 50-55, https:// doi.org/10.1016/j.jnucmat.2006.05.002.

[15] K. Splichal, J. Berka, J. Burda, M. Zmitko, Fracture toughness of the hydrogen charged EUROFER 97 RAFM steel at room temperature and 120 degrees $C$ J. Nucl. Mater. 392 (1) (2009) 125-132, https://doi.org/10.1016/ jjnucmat.2009.03.053.

[16] E. Wakai, S. Jitsukawa, H. Tomita, K. Furuya, M. Sato, K. Oka, T. Tanaka F. Takada, T. Yamamoto, Y. Kato, Y. Tayama, K. Shiba, S. Ohnuki, Radiation hardening and -embrittlement due to He production in F82H steel irradiated at 250 degrees C in JMTR, J. Nucl. Mater. 343 (1-3) (2005) 285-296, https:// doi.org/10.1016/j.j nucmat.2004.10.167.

[17] Y. Zhao, M. Liang, Z. Zhang, M. Jiang, S. Liu, Fracture toughness and fracture behavior of CLAM steel in the temperature range of 450 ć -550 ć, J. Nucl. Mater. $501 \quad$ (1) (2018) 200-207, https://doi.org/10.1016/ j.jnucmat.2018.01.039.

[18] M.A. Sokolov, H. Tanigawa, G.R. Odette, K. Shiba, R.L. Klueh, Fracture toughness and Charpy impact properties of several RAFMS before and after 
irradiation in HFIR, J. Nucl. Mater. 367 (2007) 68-73, https://doi.org/10.1016/ j.jnucmat.2007.03.165.

[19] A.F. Rowcliffe, J.P. Robertson, R.L. Klueh, K. Shiba, D.J. Alexander, M.L. Grossbeck, S. Jitsukawa, Fracture toughness and tensile behavior of ferritic-martensitic steels irradiated at low temperatures, J. Nucl. Mater. 258 (1998) 1275-1279, https://doi.org/10.1016/S0022-3115(98)00163-9.

[20] C.L. Mao, C.X. Liu, L.M. Yu, H.J. Li, Y.C. Liu, The correlation among microstructural parameter and dynamic strain aging (DSA) in influencing the mechanical properties of a reduced activated ferritic- martensitic (RAFM) steel, Mater. Sci. Eng. A-Struct. Mater. 739 (2019) 90-98, https://doi.org/10.1016/ j.msea.2018.10.023.

[21] B.S. Dutt, M.N. Babu, S. Venugopal, G. Sasikala, A.K. Bhaduri, Effect of test temperature on fracture toughness of modified $9 \mathrm{Cr}-1 \mathrm{Mo}$ steel, Mater. Sci. Technol. 27 (10) (2011) 1527-1533, https://doi.org/10.1179/0267 08310x12815992418094.

[22] G. Sasikala, S.K. Ray, Evaluation of quasistatic fracture toughness of a modified 9Cr-1Mo (P91) steel, Mater. Sci. Eng. A-Struct. Mater. 479 (1) (2008) 105-111, https://doi.org/10.1016/j.msea.2007.06.021.

[23] F.H. Huang, G.L. Wire, Fracture toughness testing on ferritic alloys using the electropotential technique, J. Nucl. Mater. 104 (1-3) (1982) 1511-1516 https://doi.org/10.1016/0022-3115(82)90814-5.

[24] P. Le Delliou, C. Sonnefraud, W. Vincent, The digital image correlation technique applied to single specimen testing methodology, in: Proceedings of the ASME Pressure Vessels and Piping Conference, 3, 2016.

[25] T.C. Chu, W.F. Ranson, M.A. Sutton, Applications of digital-image-correlation techniques to experimental mechanics, Exp. Mech. 25 (3) (1985) 232-244, https://doi.org/10.1007/bf02325092.

[26] M.A. Sutton, M.Q. Cheng, W.H. Peters, Y.J. Chao, S.R. Mcneill, Application of an optimized digital correlation method to planar deformation analysis, Image Vis Comput. 4 (3) (1986) 143-150, https://doi.org/10.1016/0262-8856(86) 90057-0.

[27] M.A. Sutton, W.J. Wolters, W.H. Peters, W.F. Ranson, S.R. McNeill, Determination of displacements using an improved digital correlation method, Image Vis Comput. 1 (3) (1983) 133-139, https://doi.org/10.1016/0262 -8856(83) 90064-1.

[28] M.Y. Zou, Y.F. Gao, Application of digital image correlation method in J-integral test of A508-3 Steel, J. Mater. Metall. 4 (2018) 269-275.

[29] P.H. Wang, J.M. Chen, H.Y. Fu, S. Liu, X.W. Li, Z.Y. Xu, Effect of N on the precipitation behaviours of the reduced activation ferritic/martensitic steel CLF-1 after thermal ageing, J. Nucl. Mater. 442 (1-3) (2013) S9-S12, https://doi.org 10.1016/j.jnuc mat.2013.03.081.

[30] Y. Gao, T. Cheng, Y. Su, X.H. Xu, Y. Zhang, Q.C. Zhang, High-efficiency and highaccuracy digital image correlation for three-dimensional measurement, Opt. Lasers Eng. 65 (2015) 73-80, https://doi.org/10.1016/j.optlase ng.2014.05.013.

[31] Y. Xue, T. Cheng, X. Xu, Z. Gao, Q. Li, X. Liu, X. Wang, R. Song, X. Ju, O Zhang High-accuracy and real-time 3D positioning, tracking system for medical imaging applications based on 3D digital image correlation, Opt. Lasers Eng. 88 (2017) 82-90, https://doi.org/10.1016/j.optlaseng.2016.07.002.

[32] Y. Xue, Y. Su, C. Zhang, X. Xu, Z. Gao, S. Wu, Q. Zhang, X. Wu, Full-field wrist pulse signal acquisition and analysis by 3D Digital Image Correlation, Opt. Lasers Eng. 98 (2017) 76-82, https://doi.org/10.1016/j.optlase ng.2017.05.018.

[33] Zhang W., Xie Y., Peng L. et al., Application of DIC method for measuring fracture toughness of three-point bend specimens for nuclear structural materials, unpublished results.

[34] ISO 12135, Metallic Materials-Unified Method of Test for the Detremination of Quasistatic Fracture Toughness, 2016.

[35] P. Moore, A. Pargeter, Comparison of using the crack mouth displacement (CMOD) and load line displacement (LLD) methods in the determination of critical J integral in SENB specimens, Fatigue Fract. Eng. Mater. Struct. 41 (9) (2018) 1997-2009, https://doi.org/10.1111/ffe.12837.

[36] C.L. Mao, C.X. Liu, L.M. Yu, H.J. Li, Y.C. Liu, Mechanical properties and tensile deformation behavior of a reduced activated ferritic-martensitic (RAFM) steel at elevated temperatures, Mater. Sci. Eng. A-Struct. Mater. 725 (2018) 283-289, https://doi.org/10.1016/j.msea.2018.03.119.

[37] C. Xu, M. Hackett, TerraPower HT9 mechanical and thermal creep properties, in: I. Charit, Y.T. Zhu, S.A. Maloy, P.K. Liaw (Eds.), Mechanical and Creep Behavior of Advanced Materials, Springer International Publishing, Cham, 2017, pp. 95-102.

[38] X. Hu, L.X. Huang, W. Yan, W. Wang, W. Sha, Y.Y. Shan, K. Yang, Low cycle fatigue properties of CLAM steel at $823 \mathrm{~K}$, Mater. Sci. Eng. A-Struct. Mater. 613 (2014) 404-413, https://doi.org/10.1016/j.msea.2014.06.069.

[39] H. Li, A. Nishimura, T. Nagasaka, T. Muroga, Stress-strain behavior on tensile and low cycle fatigue tests of JLF-1 steel at elevated temperature in vacuum, Fusion Eng. Des. 81 (23-24) (2006) 2907-2912, https://doi.org/10.1016/ j.fusengdes.2006.07.055.

[40] K. Mariappan, V. Shankar, R. Sandhya, G.V.P. Reddy, M.D. Mathew, Dynamic strain aging behavior of modified $9 \mathrm{Cr}-1 \mathrm{Mo}$ and reduced activation ferritic martensitic steels under low cycle fatigue, J. Nucl. Mater. 435 (1-3) (2013) 207-213, https://doi.org/10.1016/j.jnucmat.2012.12.049.

[41] T.S. Byun, M.B. Toloczko, T.A. Saleh, S.A. Maloy, Irradiation dose and temperature dependence of fracture toughness in high dose HT9 steel from the fuel duct of FFTF, J. Nucl. Mater. 432 (1-3) (2013) 1-8, https://doi.org/ 10.1016/j.jnucmat.2012.07.019.

[42] F.H. Huang, D.S. Gelles, Influence of specimen size and microstructure on the fracture-toughness of a martensitic stainless-steel, Eng. Fract. Mech. 19 (1) (1984) 1-20, https://doi.org/10.1016/0013-7944(84)90064-x. 